\title{
PRODUKSI BIOETANOL DARI JERAMI PADI (Oryza sativa L.) dan KULIT POHON DAO (Dracontamelon) MELALUI PROSES SAKARIFIKASI DAN FERMENTASI SERENTAK (SFS)
}

\author{
Maswati Baharuddin*, Sappewali, Karisma, Jeni Fitriyani \\ Laboratorium Biokimia, Jurusan Kimia, Fakultas Sains dan Teknologi, Universitas Islam Negeri Alauddin \\ Makassar, Jl. Sultan Alauddin No.36 Gowa Telp. (0411) 5622375 (Fax. 424836) \\ *Alamat Korespondensi: bmaswati@gmail.com
}

\begin{abstract}
Abstrak: Bioetanol merupakan energi alternatif yang dapat diproduksi dari biomassa seperti jerami padi dan biomassa berlignoselulosa. Biomassa lignoselulosa tersedia terus menerus dalam jumlah yang banyak, tetapi hanya dimanfaatkan sebagai pakan ternak, dan kadang-kadang sisanya dibakar. Jerami padi dan pohon dao memiliki komponen selulosa, hemiselulosa dan lignin. Penelitian ini bertujuan untuk mengetahui kadar glukosa yang dihasilkan melalui proses hidrolisis jerami padi dan pohon dao menggunakan enzim selulase serta menentukan kadar etanol yang dihasilkan dari proses fermentasi glukosa menggunakan Saccharomyces cerevisiae. Proses sakarifikasi dan fermentasi serentak (SFS) dilakukan dalam reaktor yang sama. Hasil penelitian menunjukkan bahwa fermentasi selama 3, 5, 7 dan 9 hari dihasilkan kadar dan konsentrasi bioetanol yang berbeda. Dari penelitian yang dilakukan kadar glukosa jerami padi adalah $105 \mathrm{mg} / \mathrm{L}$ dan dari kulit pohon dao sebanyak $216 \mathrm{mg} / \mathrm{L}$. Volume bioetanol tertinggi pada hari ke-7 dengan tingkat kemurnian tertinggi pada pohon dao $0,97 \%$ pada jerami padi dengan $0,24 \%$.
\end{abstract}

Kata kunci: Bioetanol, lignoselulosa, sakarifikasi dan fermentasi serentak

\begin{abstract}
Bioethanol is an alternative energy that can be produced from biomass such as rice straw and other lignocellulosic biomass. Lignocellusic biomass available continuously and in abundance, but has only been utilized as animal feed, and mostly burned. Rice straw has cellulose, hemicellulose and lignin components. This study aims to determine glucose level produced through rice straw hydrolysis using cellulase and to determine ethanol level produced from of rice straw fermentation process using Saccharomyces cerevisiae. The process of hydrolysis was performed using enzyme and fermentation and carried out in the same reactor which known as simultaneous saccharification and fermentation (SSF). The results of the present study showed that fermentation for 3, 5, 7 and 9 days produced different level of bioethanol. From the present research, it was found that glucose level obtained from rice straw was 105 while from dao tree $216 \mathrm{mg} / \mathrm{L}$ was obtained. The highest volume of bioetanol on day 7 with the highest purity on dao tree was $0,97 \%$ while in rice straw was 0,24\%.
\end{abstract}

Keywords: Bioethanol, lignocellulose, simultaneous saccharification and fermentation

\section{PENDAHULUAN}

Minyak bumi telah dimanfaatkan sebagai sumber kebutuhan oleh berbagai lapisan masyarakat, mulai dari kebutuhan rumah tangga sampai kebutuhan industri. Tingginya laju penggunaan minyak bumi tidak sebanding dengan laju pembentukan deposit minyak bumi di alam sehingga menyebabkan sumber energi ini akan mengalami masa krisis.

Jerami padi dan pohon-pohon seperti Dao (Dracontamelon) adalah pohon yang juga banyak mengandung biomassa lignoselulosa. Perbedaan struktur tanaman ini menyebabkan kandungan selulosa, hemiselulosa dan lignin juga berbeda. Untuk mendapatkan selulosa dari bahan yang mengandung biomassa lignoselulosa dilakukan proses delignifikasi. Proses ini penting dilakukan sebelum hidrolisis bahan selulolitik, sebab lignin dapat menghambat penetrasi asam atau enzim sebelum hidrolisis berlangsung.

Selulosa yang tinggi memungkinkan untuk dimanfaatkan sebagai media pertumbuhan mikroorganisme untuk memproduksi enzim selulase.
Jerami padi termasuk biomassa lignoselulosa yang mengandung $41,3 \%$ selulosa, 20,4\% hemiselulosa dan 12,1\% lignin (Gayang, 2013). Sedangkan selulosa pada pohon dao ini belum teridentifikasi kandungannya.

Biomassa lignoselulosa dapat dimanfaatkan sebagai sumber penghasil gula pereduksi seperti glukosa, xilosa dan maltosa. Degradasi jerami padi dan pohon dao perlu dilakukan untuk menghancurkan struktur lignin dan untuk memecah polisakarida. Degradasi lignoselulosa dapat dilakukan secara kimia, fisika dan mikrobiologis (Baharuddin et al., 2016). Larutan alkali dan asam digunakan untuk degradasi lignoselulosa secara kimia. Penggunaan metode kimia kurang efektif karena proses delignifikasi dan sakarifikasi dilakukan secara terpisah. Degradasi lignoselulosa secara mikrobiologis dilakukan dengan memanfaatkan aktivitas mikroba (Baharuddin et al., 2016). Degradasi lignoselulosa secara mikrobiologis melalui proses fermentasi (Wahyuningsih dkk., 2013).

Selulosa adalah salah satu komponen utama dari lignoselulosa yang terdiri dari unit monomer D- 
glukosa yang terikat pada ikatan 1,4-glikosidik. Selulosa cenderung membentuk mikrofibril melalui ikatan inter dan intra molekuler sehingga memberikan struktur yang larut. Mikrofibril selulosa terdiri dari 2 tipe, yaitu kristalin dan amorf (Anindyawati, 2009).

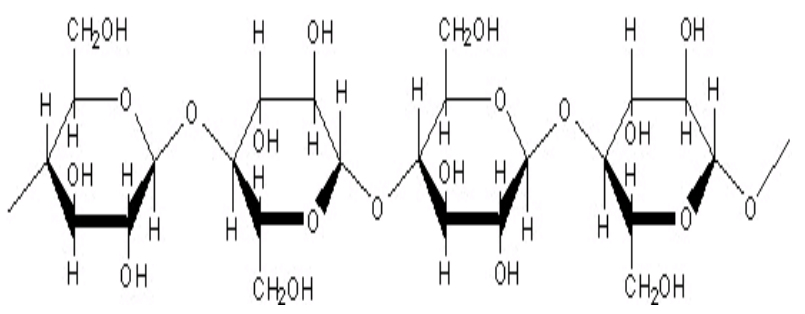

Gambar 1. Struktur Selulosa

Hemiselulosa merupakan suatu kesatuan yang membangun komposisi serat dan mempunyai peran yang penting karena bersifat hidrofilik sehingga berfungsi sebagai perekat antar selulosa yang menunjang kekuatan fisik serat. Kehilangan hemiselulosa akan mengakibatkan terjadinya lubang antar fibril dan kurangnya ikatan antar serat.

Lignin merupakan senyawa kompleks yang tersusun dari unit fenilpropana yang terikat di dalam struktur tiga dimensi dan merupakan material paling kuat di dalam massa. Lignin mengandung karbon yang relatif tinggi sehingga resisten terhadap degradasi, oleh karena itu lignin harus dipecah agar hemiselulosa dan selulosa dapat dihidrolisis.

Delignifikasi merupakan suatu proses pembebasan lignin dari suatu senyawa kompleks. Proses ini dilakukan sebelum hidrolisis bahan berlignoselulosa (Handoko dkk., 2012).

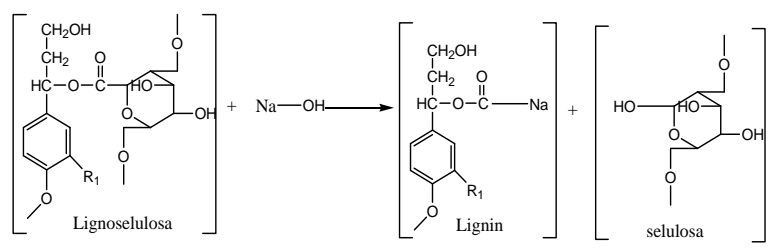

Gambar 2. Mekanisme pemutusan lignin

Kelebihan menggunakan basa $\mathrm{NaOH}$ dibandingkan $\mathrm{KOH}$ dan $\mathrm{NH}_{4} \mathrm{OH}$ karena Ion $\mathrm{OH}^{-}$ dalam $\mathrm{NaOH}$ akan memutuskan ikatan-ikatan dari struktur dasar lignin sedangkan ion $\mathrm{Na}^{+}$akan berikatan dengan lignin membentuk natrium fenolat. Garam fenolat ini bersifat mudah larut dalam pelarut polar. Lignin yang terlarut ditandai dengan warna hitam pada larutan yang disebut lindi hitam (black liquor).

Delignifikasi bertujuan untuk membuka kristalin selulosa agar selulosa lebih mudah dihidrolisis dengan enzim yang memecah polimer polisakarida dan monomer gula serta menghilangkan kandungan lignin. Delignifikasi dilakukan untuk meningkatkan jumlah dan kecepatan hidrolisis lignoselulosa (Gayang, 2013).

Enzim selulase merupakan enzim ekstraseluler (Baharuddin dkk., 2014). Enzim selulase bekerja spesifik untuk mengubah selulosa menjadi glukosa melalui tiga tahap. Tahap pertama enzim endoselulase memecah ikatan kristal selulosa yang semula berupa ikatan silang menjadi ikatan selulosa rantai lurus. Tahap kedua yaitu enzim eksoselulase memecah selulosa berantai lurus menjadi selobiose yaitu senyawa yang terdiri dari dua molekul glukosa. Tahap terakhir yaitu enzim selobiose yaitu mengubah selobiose menjadi molekul-molekul glukosa (Kamila, 2003). Produksi enzim selulase secara komersial biasanya menggunakan kapang atau bakteri (Baharuddin dkk., 2014). Kapang yang biasanya menghasilkan enzim selulase adalah Aspergillus niger, Trichoderma viride, dan lain lain, sedangkan bakteri yang bisa menghasilkan enzim selulase adalah Pseudomonas, Cellulomonas dan Bacillus (Gunam dkk., 2011).

Proses Sakarifikasi dan Fermentasi Serentak (SFS). Satu diantara beberapa keuntungan dari proses SSF adalah hidrolisis dan fermentasi dilakukan dalam satu wadah atau reaktor sehingga dapat berlangsung secara efisien (Samsuri dkk., 2007).

Penelitian sebelumnya oleh Wahyuliani (2014), menyatakan, jerami padi mengandung komponen berat kering yang terdiri dari $22 \%$ lignolselulosa, $12 \%$ lignin dan $31 \%$ selulosa. Penelitian Ariyani dkk., (2013), bahwa kadar glukosa yang terkandung dalam jerami padi yaitu sebanyak 70,85 ppm dan kadar etanol pada jerami padi yaitu sebesar 6,405\% dengan waktu fermentasi 13 hari.Semakin lama proses sakarifikasi dan fermentasi serentak (SFS) maka semakin tinggi kadar bioetanol yang dihasilkan dan waktu optimum pembentukan bioetanol yaitu 7 hari serta semakin tinggi konsentrasi ragi yang digunakan maka semakin tinggi pula kadar bioetanol yang dihasilkan.

\section{BAHAN DAN METODE Bahan}

Bahan yang digunakan pada jerami padi diperoleh pada daerah Takalar dan Pohon Dao Dracontamelon diperoleh pada kawasan hutan Lejja, amonium molibdat, asam klorida, asam sulfat pekat, Aspergillus niger, batu didih, glukosa, dinatrium hidro arsenat anhidrat, diamonium sulfat, etanol $70 \%$, kalium dikromat, kalium hidroksida kupri sulfat pentahidrat, natrium bikarbonat, natrium karbonat , natrium hidroksida $0,5 \mathrm{~N}$, natrium kalium tartrat, natrium sulfat, kalium hidrogen fosfat, Potato Dextrose Agar (PDA) dan urea.

\section{Perlakuan Fisik dan Penghilangan Lignin}

Jerami padi dan kulit pohon Dao Draconta melon dijemur selama 2 hari kemudian dipotong kecil, lalu dikeringkan dengan oven selama 4 jam pada suhu $60^{\circ} \mathrm{C}$, digerus, serbuk jerami padi kemudian diayak 
dengan menggunakan ayakan 100 mesh sehingga diperoleh serbuk jerami padi dan serbuk pohon dengan ukuran $100 \mu \mathrm{m}$. ditimbang 10 gram serbuk jerami padi ke dalam Erlenmeyer $250 \mathrm{~mL}$ lalu ditambahkan natrium hidroksida $0,5 \mathrm{~N}$ sebanyak 100 $\mathrm{mL}$ lalu dioven selama 24 jam pada suhu $105^{\circ} \mathrm{C}$ kemudian disaring, serbuk jerami padi dibilas dengan aquadest hingga $\mathrm{pH}$ netral (diuji dengan kertas lakmus) dikeringkan dalam oven selama 2 jam pada suhu $100^{\circ} \mathrm{C}$, digerus dan diayak dengan ayakan 100 mesh hasil perlakuan ini yaitu serbuk selulosa. Proses yang sama dilakukan juga pada serbuk pohon dao.

\section{Penyiapan Inokulum dari Aspergillus niger}

Sebanyak $100 \mathrm{ml}$ media cair (media cair ini terdiri dari glukosa 1 gram dan nutrien broth (NB) 0,8813 gram) dimasukkan ke dalam erlenmeyer dan $\mathrm{pH}$ media cair dengan asam klorida diatur hingga $\mathrm{pH}$ 3. Kawat ose dicelupkan ke dalam etanol $96 \%$ lalu dipanaskan pada api bunsen sampai berwana merah. Ambil biakan Aspergillus niger dari media PDA dengan menggunakan kawat ose lalu dicelupkan beberapa saat pada media cair hingga tampak keruh. Media cair ditutup dengan kapas dan diletakkan pada rotary shaker selama 48 jam dengan kecepatan 130 rpm hingga diperoleh suspensi Aspergillus niger.

\section{Pembuatan Enzim Selulase Dari Medium Cair Padat}

Ditimbang 10 gram serbuk jerami padi lalu dimasukkan ke dalam gelas kimia $250 \mathrm{~mL}$ dan ditambahkan nutrisi urea 0,0159 gram, magnesium sulfat heptahidrat sebanyak 0,0026 gram, kalium hidrogen pospat 0,0013 gram dan $80 \mathrm{~mL}$ aquadest kemudian diatur $\mathrm{pH}$ media menggunakan asam klorida hingga $\mathrm{pH} 5$ lalu media disterilkan di dalam autoclave pada suhu $120^{\circ} \mathrm{C}$ selama 15 menit. Media yang telah disterilkan kemudian didinginkan dan suspensi spora Aspergillus niger sebanyak $10 \mathrm{~mL}$ pada media tersebut lalu media diinkubasi pada suhu $\pm 30^{\circ} \mathrm{C}$ dengan waktu fermentasi 96 jam. Hasil fermentasi diekstrak dengan aquadest sebanyak 100 $\mathrm{mL}$ kemudian di letakkan pada rotary shaker selama 1 jam dengan kecepatan $150 \mathrm{rpm}$ dan cairan hasil fermentasi dipisahkan dengan menggunakan kertas saring. Enzim yang diperoleh kemudian disimpan di lemari pendingin dan siap digunakan.

\section{Proses Sakarifikasi dan Fermentasi Serentak}

Sebanyak 20 gram serbuk jerami padi yang berukuran 100 mesh ditambahkan aquadest $100 \mathrm{~mL}$ dan diatur $\mathrm{pH}$ kemudian dipanaskan dalam autoklaf pada suhu $121^{\circ} \mathrm{C}$ selama 15 menit. Bubur jerami padi dibiarkan hingga dingin. Kemudian ditambahkan enzim selulase sebanyak $10 \mathrm{~mL}$ untuk proses hidrolisis dan ditutup rapat. Selanjutnya dikocok dengan kecepatan 170 rpm selama 24 jam. Setelah itu ditambahkan Saccaromyces cerevisiae sebanyak 4 gram diaduk dengan kecepatan 150 rpm sampai homogen. Fermentasi dimulai dengan adanya penambahan yeast ini. Kemudian erlenmeyer ditutup dengan penutup yang dilengkapi dengan selang karet yang ujung selang dimasukkan ke dalam air agar tidak terjadi kontak dengan udara. Sakarifikasi dan fermentasi dilanjutkan selama 3, 5, 7 dan 9 hari. Selanjutnya larutan hasil SFS dipisahkan dari bubur jerami. Larutan tersebut didistilasi pada suhu $80^{\circ} \mathrm{C}$ selama 1,5 - 2 jam sampai etanol tidak menetes lagi. Diukur destilat etanol yang diperoleh. Proses yang sama dilakukan juga pada pohon dao. Uji kadar glukosa dilakukan dengan menggunakan metode Nelson Samogy.

\section{HASIL DAN PEMBAHASAN}

Kadar Glukosa Jerami Padi dan Kulit Pohon Dao

Kadar glukosa dari selulosa hasil delignifikasi jerami padi menggunakan larutan natrium hidroksida 0,5 N. Metode penentuan kadar glukosa yaitu dengan analisis kuantitatif menggunakan spektrofotometer UV-Vis dengan pereaksi Nelson-Samogy menghasilkan data yang ditunjukkan pada Tabel 1 .

Tabel 1. Perbandingan kadar glukosa jerami padi dan pohon dao setelah proses delignifikasi

\begin{tabular}{cc}
\hline Sampel & $\begin{array}{c}\text { Kadar } \\
\text { Glukosa } \\
\text { (mg/L) }\end{array}$ \\
\hline Jerami padi & 105 \\
\hline Pohon dao & 216 \\
\hline
\end{tabular}

Berdasarkan penelitian yang telah dilakukan, tahap awal delignifikasi yaitu proses penghilangan lignin. Proses delignifikasi menggunakan larutan natrium hidroksida $0,5 \mathrm{~N}$. Hasil delignifikasi terjadi perubahan warna menjadi kehijauan. Larutan $\mathrm{NaOH}$ dapat menyerang dan merusak struktur lignin pada bagian kristalin dan amorf serta memisahkan sebagian hemiselulosa.

Kadar glukosa yang dihasilkan dari proses hidrolisis menggunakan enzim selulase (sakarifikasi) yaitu lebih besar untuk pohon dao sebanyak 216 $\mathrm{mg} / \mathrm{L}$ dibadingkan jerami yaitu $105 \mathrm{mg} / \mathrm{L}$. Hal ini disebabkan karena biomassa lignoselulosa pohon lebih banyak mengandung selulosa. Untuk mengetahui adanya glukosa dari hasil hidrolisis selulosa jerami padi yaitu dengan menggunakan pereaksi Benedict yang menghasilkan larutan berwarna kuning kehijauan dan endapan jingga.

\section{Kadar Bioetanol Jerami Pada Proses Sakarifikasi dan Fermentasi Serentak (SFS)}

Kadar bioetanol jerami padi dari proses sakarifikasi dan fermentasi serentak (SFS) yaitu dengan analisis kualitatif menggunakan spektrofotometer FTIR dan kuantitatif menggunakan Gas Chromatography (GC) sehingga didapatkan data yang ditunjukkan pada Tabel 2. 
Berdasarkan penelitian yang telah dilakukan kadar bioetanol jerami padi terjadi peningkatan dari hari ke-3 sampai hari ke-7. Kadar etanol sebesar teringgi pada hari ke-7 sebesar 0,24\%. Volume dan kadar bioetanol meningkat dengan bertambahnya waktu fermentasi. Peningkatan waktu fermentasi meningkatkan kadar bioetanol yang dihasilkan. Hal ini disebabkan karena waktu kontak antara khamir Saccharomyces cereviceae dengan sumber karbon (glukosa) semakin lama sehingga menghasilkan bietanol yang lebih banyak (Widayanti dkk., 2016). Setelah waktu optimum tercapai maka volume etanol yang dihasilkan menurun. Hal ini disebabkan karena substrat yang dikonversi menjadi produk oleh mikroorganisme telah habis dan bioetanol yang dihasilkan telah berubah menjadi asam asam organik seperti asam cuka.

\section{Kadar Bioetanol Pohon Dao Proses Sakarifikasi dan Fermentasi Serentak (SFS)}

Kadar bioetanol dari kulit pohon Dao tertinggi dicapai juga pada waktu fermentasi 7 hari yaitu 10 mL dengan kadar etanol 0,97\%. Etanol banyak diproduksi pada hari ke 7 karena pada hari ke 7 Sacharomyces cereviseae mengalami fase pertumbuhan stasioner yang konstan. Dimana, pada fase ini Sacharomyces mengalami perbanyakan sel yang sangat banyak dan aktifitas sel meningkat karena pemecahan gula yang cukup besar.

Tabel 2. Kadar bioetanol jerami padi dengan variasi waktu fermentasi

\begin{tabular}{ccccc}
\hline $\begin{array}{c}\text { Lama } \\
\begin{array}{c}\text { Fermentasi } \\
\text { (hari) }\end{array}\end{array}$ & $\begin{array}{c}\text { Waktu } \\
\text { Retensi } \\
(\mathbf{m m})\end{array}$ & $\begin{array}{c}\text { Area } \\
{[\mathbf{p A} \text { *] }}\end{array}$ & $\begin{array}{c}\text { Volume } \\
\text { etanol } \\
(\mathbf{m L})\end{array}$ & $\begin{array}{c}\text { Kadar } \\
\text { Bioetanol } \\
(\boldsymbol{\%})\end{array}$ \\
\hline 3 & 2,698 & 247532 & 10 & 0,071 \\
5 & 2,690 & 424720 & 16 & 0,122 \\
7 & 2,703 & 842518 & 20 & 0,242 \\
9 & 2,697 & 88200 & 8 & 0,025 \\
\hline
\end{tabular}

Tabel 3. Kadar bioetanol dari pohon Dao dengan variasi waktu fermentasi

\begin{tabular}{ccccc}
\hline $\begin{array}{c}\text { Lama } \\
\text { Fermentasi } \\
\text { (hari) }\end{array}$ & $\begin{array}{c}\text { Waktu } \\
\text { Retensi } \\
(\mathbf{m i n})\end{array}$ & $\begin{array}{c}\text { Area } \\
{\left[\mathbf{p A} \mathbf{*}^{*}\right]}\end{array}$ & $\begin{array}{c}\text { Volume } \\
\text { destilat } \\
(\mathbf{m L})\end{array}$ & $\begin{array}{c}\text { Kadar bioetanol } \\
(\boldsymbol{\%})\end{array}$ \\
\hline 3 & 2,710 & 2415174 & 6 & 0,694 \\
5 & 2,696 & 1017773 & 9 & 0,292 \\
7 & 2,713 & 3405941 & 10 & 0,978 \\
9 & 2,713 & 1744754 & 6 & 0,050 \\
\hline
\end{tabular}

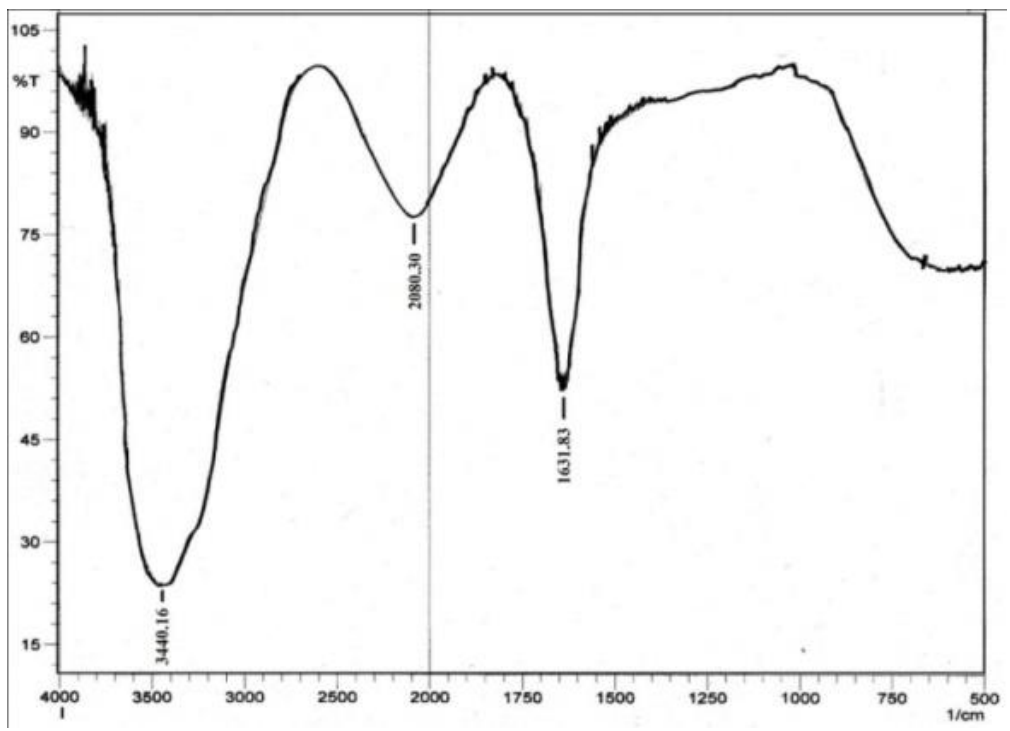

Gambar 3.Spektra FTIR bioetanol hasil jerami padi 


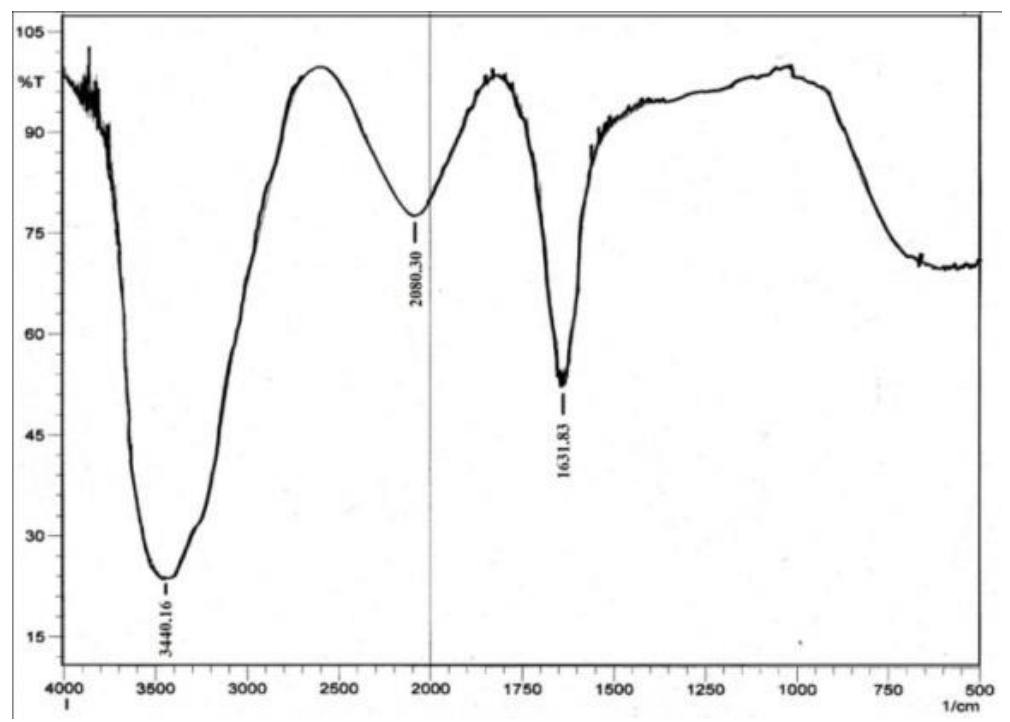

Gambar 4. Spektra FTIR hasil IR kulit pohon Dao

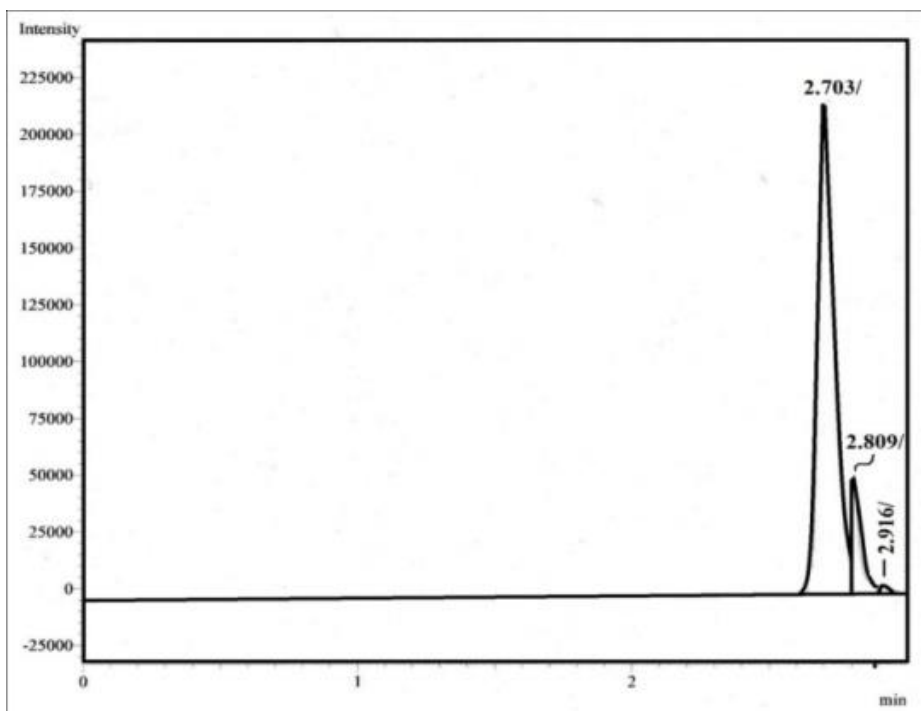

Gambar 5. Kromatogram GC bioetanol hasil fermentasi glukosa Jerami padi 7 hari

Pada hari ke 3 etanol yang dihasilkan sebanyak $6 \mathrm{~mL}$, Sacharomyces baru mengalami fase lag, fase dimana Sacharomyces mulai menyesuaikan sel-sel dengan lingkungan pembentukkan enzim-enzim untuk mengurai substrat. Menurut Fajrin dkk. (2012) semakin lama waktu fermentasi, maka konsentrasi sel mikroorganisme akan semakin menurun dan menuju pada fase kemtian karena konsentrasi bioetanol yang dihasilkan semakin tinggi dan konsentrasi nutrien sebagai makanan mikroorganisme semakin menurun.

Uji kualitatif destilat (etanol) yang dilakukan yaitu dengan melakukan uji nyala. Uji kualitatif selanjutnya yaitu memanaskan destilat dalam tabung reaksi yang ditutup dengan kertas saring yang sebelumnya telah dibasahi oleh asam sulfat $2 \mathrm{M}$ dan ditetesi dengan Kalium dikromat $2 \mathrm{M}$ ditandai dengan berubahnya kertas saring dari kuning menjadi hijau kebiruan. $\mathrm{Cr}^{6+}$ yang berwarna kuning akan tereduksi menjadi $\mathrm{Cr}^{3+}$ yang berwarna biru karena alkohol teroksidasi menjadi aldehid.

Hasil uji kualitatif bioetanol menggunakan Fourier Transform Infra Red (FTIR). Spektrum hasil analisa FTIR destilat (etanol) menunjukkan adanya serapan gugus $-\mathrm{OH}$ pada bilangan gelombang $3440,16 \mathrm{~cm}^{-1}$, pada bilangan gelombang $1631,83 \mathrm{~cm}^{-1}$ menunjukkan adanya serapan gugus $\mathrm{CH}_{2}$

Terlihat pada Gambar 3 karakteristik spektra yang dihasilkan dilihat dari puncak-puncak yang 
dibentuk oleh gugus fungsi. Dari hasil analisa FTIR terdapat serapan gugus $\mathrm{OH}$ pada panjang gelombang $3438,23 \mathrm{~cm}^{-1}$ dan serapan gugus $\mathrm{CH}$ pada panjang gelombang 2360,95 $\mathrm{cm}^{-1}$ dan 2332,96 $\mathrm{cm}^{-1}$

Gambar 5 menjelaskan bahwa etanol yang dihasilkan dari hasil fermentasi akan keluar pada waktu retensi sekitar 2,69 menit dengan luas area yang berbeda-beda dan semakin luas dengan bertambahnya waktu fermentasi. Luas area tertinggi yaitu pada hari ke 7 yaitu sebesar 842518, waktu retensi 2,703 menit dengan konsentrasi etanol sebesar $0,24 \%$.

\section{KESIMPULAN}

Kadar glukosa dalam 20 gram selulosa jerami padi 105 dan $216 \mathrm{mg} / \mathrm{L}$. Kadar etanol selulosa jerami padi melalui proses sakarifikasi dan fermentasi serentak (SFS) yaitu $0,24 \%$. sedangkan pada pohon dao sebesar $0,97 \%$.

\section{DAFTAR PUSTAKA}

Anindyawati, T. (2009). Prosepek enzim dan limbah lignoselulosa untuk produksi bioetanol, Berita Selulosa, 44(1): 49-56.

Ariyani, E., Kusumo, E., Supartono. (2013). Produksi bioetanol dari jerami padi (Oryza sativa L.), Indonesian Journal of Chemical Science, 2(2): 167-172.

Baharuddin, M., Patong, R., Ahmad, A., La Nafie, N. (2014a). Pengaruh suhu dan $\mathrm{pH}$ terhadap hidrolisis CMC oleh enzim selulase dari isolat bakteri larva Cossus cossus, Jurnal Teknosasins dan Teknologi, 8(3): 343-356.

Baharuddin, M., Patong, R., Ahmad, A., La Nafie, N. (2014b). Isolasi dan karakterisasi bakteri simbion larva kupu-kupu Cossus cossus penghasil selulase, Al-Kimia, 2(2): 58-68.

Baharuddin, M., Ahmad, A., La Nafie, N., Zenta, F., (2016). Cellulase enzyme activity of bacillus circulans from larvae Cossus cossus in lignocellulosic substrate, American Journal of Biomedical and Life Sciences, 4(2): 21-25.
Fajrin I., Amriani S.Z., Muria, S.R. (2011). Pengaruh volume inokulum pada produksi bioetanol dari limbah kulit nanas menggunakan Zymomonas mobilis dengan metode solid state fermentation (SSF), Jurnal Online Mahasiswa, 1(1): 1-5.

Gayang, F. (2013). Konversi lignoselulosa tandan kosong kelapa sawit menjadi gula pereduksi menggunakan enzim xilanase dan selulase komersial, Skripsi. Bogor: Departeman Kimia, Fakultas Matematika dan Ilmu Pengetahuan Alam, IPB.

Gunam, I.B.W., Aryanta, W.R. \& Darma, I.B.N.S. (2011), Produksi selulase kasar dari kapang trichoderma viride dengan perlakuan konsentrasi substrat ampas tebu dan lama fermentasi, Jurnal Biologi, 15(2): 29-33.

Handoko, T., Suhandjaja G. \& Muljana, H. (2012). Hidrolisis serat selulosa dalam buah bintaro sebagai sumber bahan baku bioetanol, Jurnal Teknik Kimia Indonesia, 11(1): 26-33.

Kamila, L. (2003). Pencirian selulolitik isolat khamir Rhodotorula sp. dari tanah hutan taman nasional gunung halimun, Skripsi. Bogor: Departeman Kimia, Fakultas Matematika dan Ilmu Pengetahuan Alam, IPB.

Samsuri, M., Gozan M., Mardias, R., Baiquni M., Hermansyah, H., Wijanarko, A., Prasetya, B. \& Nasikin, M. (2007). Pemanfaatan selulosa bagas untuk produksi ethanol melalui sakarifikasi dan fermentasi serentak dengan enzim xylanase, Makara Teknologi, 11(1): 17-24.

Wahyuliani, D. (2014). Hidrolisis lignoselulosa dan selulosa jerami padi enzim selulase dari isolat bakteri termofilik, Skripsi Jurusan Kimia Fakultas Sains dan Teknologi.

Wahyuningsih, M., Sarjono, P.R., Aminin, A.L.N. (2013) Biokonversi Jerami Padi Menjadi Gula Fermentasi Menggunakan Konsorsium Termofilik Kompos, Jurnal Sains dan Matematika, 21(1): 7-14

Widayanti S N., Mappiratu, M. \& Hardi, J., 2016, Optimalisasi penerapan Bioetaknologi dalam produksi bioetanol dari Sagu (Metroxylon sp.), Natural Sciences: Journal of Science and Technology, 5(1): 41-48. 